Jurnal Ilmu Komunikasi UHO : Jurnal Penelitian Kajian Ilmu Komunikasi dan Informasi.

Volume 6, No. 1, Januari 2021, hlm 77-97

\title{
ANALISIS STRATEGI PEMULIHAN CITRA JOKOWI DALAM MENGATASI WABAH COVID-19 DI INDONESIA
}

\author{
Mustafa $^{1)}$, Assyari Abdullah ${ }^{2)}$, Jayus $^{3)}$ \\ 1) 2 Program Studi Ilmu Komunikasi Fakultas Dakwah dan Komunikasi Universitas Islam \\ Negeri Sultan Syarif Kasim Riau \\ ${ }^{3)}$ Program Studi Ilmu Komunikasi Fakultas Ilmu Komunikasi Universitas Muhammadiyah \\ Riau \\ 1) 2 ) Jalan HR Soebrantas Nomor 155 Kota Pekanbaru, Riau \\ ${ }^{3)}$ Jalan Tuanku Tambusai, Kota Pekanbaru, Riau
}

Email: mustafa@uin-suska.ac.id, assyariabdullah@uin-suska.ac.id, jayus@umri.ac.id

\begin{abstract}
ABSTRAK
Penyebaran wabah virus korona masih terus terjadi di berbagai negara. Indonesia adalah salah satu negara yang terpapar wabah, sehingga berdampak ke berbagai sektor kehidupan warganya. Presiden Jokowi menjawab berbagai kritikan terkait penanganan dan penanggulangan COVID-19 di Indonesia melalui wawancara khusus dengan Najwa Shibab dalam acara Mata Najwa di Trans 7 pada 23 April 2020. Dengan melakukan analisis retoris dan pendekatan restorasi citra Benoit, penelitian ini berusaha untuk melihat bagaimana strategi pesan pemerintah dalam menjawab berbagai tuduhan terkait COVID-19. Hasil penelitian menunjukkan Jokowi berusaha memoles citranya dengan melakukan beberapa strategi antara lain penyangkalan, serang penuduh, diferensiasi, kekalahan, kecelakaan, memperkuat, dan tindakan perbaikan. Jokowi dalam perbaikan citra pemerintah cenderung memakai strategi bertahana yakni memperbanyak strategi diferensiasi dan defeasibility, serta niat baik. Meski ada penyangkalan tetapi Jokowi juga sangat hati-hati menyerang para penuduhnya.
\end{abstract}

Kata-kata Kunci: Strategi; Pemulihan Citra; ;COVID-19; Jokowi 
Jurnal Ilmu Komunikasi UHO : Jurnal Penelitian Kajian Ilmu Komunikasi dan Informasi.

Volume 6, No. 1, Januari 2021, hlm 77-97

\title{
ANALYSIS OF JOKOWI'S IMAGE RESTORATION STRATEGY IN OVERCOMING COVID-19 OUTBREAK IN INDONESIA
}

\begin{abstract}
The spread of the coronavirus outbreak continues to occur in various countries. Indonesia is one of the countries affected by the plague, which affects various sectors of the lives of its citizens. President Jokowi answered various criticisms related to the handling and handling of COVID-19 in Indonesia through a special interview with Najwa Shibab during the Mata Najwa event at Trans 7 on April 23, 2020. By conducting a rhetorical analysis and Benoit image restoration approach, this study seeks to see how the message strategy is. the government in responding to various accusations related to COVID-19. The results showed that Jokowi tried to polish his image by carrying out several strategies including denial, attacking the accusers, differentiation, defeat, accidents, strengthening, and corrective action. Jokowi in improving the government's image tends to use a defensive strategy, namely increasing differentiation and defeasibility strategies, as well as good intentions. Despite denials, Jokowi was also very careful about attacking his accusers.
\end{abstract}

Keywords: Strategy; Image Restoration; ; COVID-19; Jokowi 
Jurnal Ilmu Komunikasi UHO : Jurnal Penelitian Kajian Ilmu Komunikasi dan Informasi.

Volume 6, No. 1, Januari 2021, hlm 77-97

\section{PENDAHULUAN}

Penyebaran wabah virus corona masih terus terjadi di berbagai negara. Indonesia adalah salah satu negara yang terpapar wabah ini. Sampai dengan akhir Mei 2020 sekitar 23 ribu orang terkonfirmasi mengidap virus ini di Indonesia.(COVID-19, 2020) Pemerintah dinilai lamban dan kurang efektif dalam menangani pandemi Corona. Survey Kompas menyebutkan sekitar 42,8 persen publik menilai pemerintah kurang cepat dan kurang efektif dalam menangani penyebaran, bahkan 16.4 persen ada yang mengangap sikap pemerintah sudah mengecewakan dari awal. (Pranita, 2020).

Pemerintah dikritik antara lain melewatkan penanganan di masa awal COVID-19 yakni di Januari dan Februari, serta tak serius soal Pembatasan Sosial Berskala Besar (PSBB). (Persada, 2020a). Pemerintah juga dituduh kurang transparan mengenai data COVID-19. Ikatan Dokter Indonesia (IDI) menyebut bahwa angka kematian akibat COVID19 di Indonesia yang disampaikan pemerintah belum menggambarkan angka sebenarnya seperti yang terjadi di lapangan, (Bramasta, 2020). Lembaga pembela Hak Asasi Manusia, Human Rights Watch menilai pemerintah Indonesia gagal menyediakan akses dan transparansi informasi kepada publik mengenai pencegahan wabah COVID-19 (Persada, 2020b).

Program pemerintah dalam penanganan dampak COVID-19 seperti Kartu Pra Kerja juga tak luput dari kritik mulai dari insentif pelatihan sampai penunjukan mitra (Bernie, 2020a). Kemudian kebijakan larangan mudik yang dinilai tidak terukur, terutama soal peraturan yang juga kurang tegas (Prayogo, 2020). Pendistribusian warga penerima bantuan sosial juga menuai kritik mulai dari pendataan yang tidak sinkron antara pusat dan daerah sampai masalah distribusi yang tak tepat sasaran.(CNN Indonesia, 2020a).

Pemerintah menunjukkan keseriusan dalam penanganan COVID-19 dengan mengalokasikan tambahan Anggaran Pendapatan dan Belanja Negara (APBN) untuk penanganan sebesar Rp 405,1 triliun. Tambahan anggaran belanja itu dialokasikan untuk bidang kesehatan termasuk insentif tenaga medis $\mathrm{Rp} 75$ triliun, jaring pengamanan sosial (social safety nett) kepada warga Rp 110 triliun, dukungan untuk sektor industri Rp 70,1 triliun, dan dukungan pembiayaan anggaran untuk COVID-19 Rp 150 triliun (Ulya, 2020)

Pemerintah juga menjawab tuduhan dan harapan rakyat dengan sejumlah kebijakan yang diumumkan setiap hari melalui konferensi pers dan diliput oleh media. Melalui 
Jurnal Ilmu Komunikasi UHO : Jurnal Penelitian Kajian Ilmu Komunikasi dan Informasi.

Volume 6, No. 1, Januari 2021, hlm 77-97

konferensi pers dan rilis yang dibuat Gugus Tugas Percepatan Penanganan COVID-19 pemerintah mengkomunikasikan apa yang sedang terjadi dan apa saja yang sudah dan akan dikerjakan. Gugus Tugas juga meluncurkan aplikasi Bersatu Lawan Covid-19. (Kominfo, 2020a).

Presiden Jokowi selaku kepala pemerintahan bahkan menyediakan waktu wawancara khusus dengan Najwa Shihab di acara Mata Najwa, Rabu, 23 April 2020, untuk merespons berbagai kritik yang ditujukan kepada pemerintah. Studi ini meneliti strategi pesan yang digunakan pemerintah dalam memulihkan citranya dalam penangangan Covid-19 melalui program Mata Najwa talkshow politik paling populer dan paling banyak ditonton di Indonesia menurut survey Cyrus Network (Bernie, 2020b).

Merujuk kepada latar belakang diatas, penulis ingin mendiskusikan tentang bagaimana Strategi Pemulihan Citra Jokowi Dalam Mengatasi Wabah Covid-19 di Indonesia yang akan dinarasikan pada apa yang disebut model Introduction, Body and Conclusion (IBC) (Martín, 2014) dalam artikel ini.

\section{Literatur Review}

Dalam masa krisis, komunikasi dan kepemimpinan menjadi kunci. Ketika keadaan mulai diatasi, pentingnya berkomunikasi dalam krisis mencapai puncaknya. Sama pentingnya bagi bangsa untuk mendengar dari presiden, atau presiden sebuah perusahaan untuk mendengar dari para karyawannya. (Flynn, 2004). Pada dasarnya, komunikasi krisis dapat melakukan tiga fungsi: informasi instruktif yang menginformasikan orang tentang bagaimana bereaksi dalam hal perlindungan pribadi, informasi penyesuaian yang membantu orang untuk mengatasi ketidakpastian, dan menginternalisasi informasi yang merujuk pada informasi yang membantu organisasi mengelola reputasinya (Sturges, 1994).

Informasi yang menginternalisasi dapat dipahami mengingat bahwa teori-teori komunikasi krisis berasal dari gagasan apologia, yang dijelaskan dalam literatur retorika klasik sebagai seni mempertahankan posisi (Hearit, 1999). Sesuai dengan tradisi ini, komunikasi krisis berfokus pada pengembangan strategi retorik dengan tujuan mengurangi kesalahan dan membantu organisasi atau perusahaan terkemuka, untuk kembali ke kegiatan sehari-hari mereka dengan sedikit kerusakan pada reputasi mereka (Coombs \& Holladay, 2010). Salah satu kontribusi teoretis yang penting untuk bidang ini adalah Teori Perbaikan 
Jurnal Ilmu Komunikasi UHO : Jurnal Penelitian Kajian Ilmu Komunikasi dan Informasi.

Volume 6, No. 1, Januari 2021, hlm 77-97

Citra Benoit (W. L. Benoit, 2015) yang mengkategorikan berbagai jenis strategi restorasi citra retoris yang ditujukan untuk mengurangi efek negatif dari krisis.

Citra juga penting untuk organisasi, termasuk badan pemerintah (W. L. Benoit, 1997). Citra dapat dianggap sebagai persepsi seseorang atau organisasi atau pemerintah yang dipegang oleh orang lain, organisasi, atau pemerintah karena citra seseorang dipengaruhi oleh kata-kata dan tindakannya sendiri, serta oleh wacana dan perilaku orang lain (W. L. Benoit \& Brinson, 1999). Citra organisasi atau pemerintah juga dapat dipengaruhi oleh kata-kata dan tindakan wakilnya, seperti serta wacana dan perilaku organisasi atau pemerintah lain.

Relatif sedikit penelitian yang mengeksplorasi bagaimana pemerintah mencoba memperbaiki citra pemerintah ketika beresiko. Zhang dan Benoit (J. Zhang \& Benoit, 2004) menyelidiki upaya perbaikan citra oleh Arab Saudi setelah serangan terhadap Amerika pada 9/11. Sebanyak 15 dari 19 pembajak adalah warga negara Arab Saudi. Pemerintah Saudi sebagian besar mengandalkan penyangkalan dan penguatan dan cukup berhasil dalam menghadapi tuduhan bahwa mereka mendukung terorisme; itu kurang efektif dalam menangani kekhawatiran bahwa Arab Saudi belum cukup mendukung AS di Irak. Drumheller dan Benoit (Drumheller \& Benoit, 2004) meneliti upaya Angkatan Laut AS untuk menangani korban Jepang ketika kapal selam USS Greeneville bertabrakan dengan pukat ikan, Ehime Maru. Analisis ini juga membahas pentingnya upaya diplomatik dalam perbaikan citra, terutama ketika masalah budaya sedang dimainkan. Mortifikasi digunakan tetapi tidak seefektif yang seharusnya: norma-norma budaya di Jepang menetapkan bahwa permintaan maaf harus dilakukan secara langsung kepada keluarga korban.

Berkaitan dengan strategi krisis kesehatan, Di Staso, dkk (DiStaso et al., 2015) menilai strategi simpati krisis mengakibatkan kepercayaan dan reputasi pasca-krisis lebih rendah daripada informasi stakeholder yang menerima pesan informasi lebih mungkin membagikannya, mencari informasi tambahan, dan kembali ke rumah sakit daripada mereka yang menerima tanggapan simpati atau permintaan maaf. Praktisi hubungan masyarakat harus menghindari memposting postingan simpatik selama krisis kesehatan karena mereka dapat lebih merusak citra organisasi yang terkena dampak. Sebaliknya, melakukan pendekatan proaktif dengan memposting pesan informatif dapat terbukti lebih menguntungkan 
Jurnal Ilmu Komunikasi UHO : Jurnal Penelitian Kajian Ilmu Komunikasi dan Informasi.

Volume 6, No. 1, Januari 2021, hlm 77-97

Joanne E Hale, dkk (Hale et al., 2005) menguji tantangan komunikasi yang dialami oleh para pembuat keputusan selama tahap respons manajemen krisis. Respons mungkin yang paling kritis dari tiga tahap (pencegahan, tanggapan, pemulihan) yang diidentifikasi dalam literatur penelitian krisis. Respons adalah titik dimana manajer krisis membuat keputusan yang dapat menyelamatkan nyawa dan mengurangi dampak krisis. Tindakan pada titik ini juga secara signifikan mempengaruhi opini publik tentang krisis dan penanganan organisasi terhadap peristiwa tersebut. Hasil analisis ini adalah identifikasi dan eksplorasi empat langkah respons krisis: observasi, interpretasi, pilihan, dan penyebaran.

Zhang dan Benoit (E. Zhang \& Benoit, 2009) menganalisis wacana perbaikan citra oleh Menteri Kesehatan Tiongkok Zhang Wenkang tentang virus SARS. Menteri itu menghadapi beberapa tuduhan: wabah SARS terus bertambah, pemerintah Cina telah menutupi parahnya masalah ini, pemerintah juga mengabaikan orang Taiwan yang menderita SARS, dan Kementerian Kesehatan memberikan informasi yang tidak tepat waktu atau akurat. Dia menggunakan beberapa strategi perbaikan citra antara lain penolakan, defeasibility, memperkuat, minimisasi, diferensiasi, penuduh serangan, dan tindakan korektif. Namun, pesannya kontradiktif dan tampaknya terkait dengan informasi palsu, sehingga usahanya tidak berhasil dan ia dilucuti dari kantornya.

Argenti berpendapat dalam krisis yang bergerak cepat, penting bagi para pemimpin untuk berkomunikasi dengan konstituensi utama mereka, sejak awal, sering, dan dengan empati, kejujuran, dan transparansi - bahkan ketika pemimpin tidak memiliki semua jawaban. Mulailah dengan menyusun tim komunikasi terpusat. Meskipun komunikasi desentralisasi mungkin diinginkan dalam organisasi besar, dan kompleks, namun dalam situasi darurat atau bergerak cepat, diperlukan tim komunikasi krisis yang terdiri dari para pemimpin kunci. Dengan corona virus, kita melihat ini terjadi disemua tingkatan: Presiden Trump menunjuk Wakil Presiden Pence untuk memimpin upaya nasional mengatasi COVID-19. (Argenti, 2020). Di Indonesia Presiden Jokowi membentuk Gugus Tugas Percepatan Penanganan COVID-19 melalui Keputusan Presiden Nomor 7 Tahun 2020 (Kominfo, 2020b).

Pemerintah AS telah memberikan informasi yang serampangan dan kontradiktif (Lopez 2020), mempengaruhi kepercayaan dan reaksi publik (Sanders 2020). Presiden Trump telah beberapa kali menentang ahli kesehatan masyarakatnya sendiri, menabur kebingungan tentang tingkat keparahan dan karakteristik virus (Abadi et al. 2020). Pemerintah juga dapat menimbulkan kontroversi dengan terlibat dalam spekulasi. Pemerintah dapat menciptakan 
Jurnal Ilmu Komunikasi UHO : Jurnal Penelitian Kajian Ilmu Komunikasi dan Informasi.

Volume 6, No. 1, Januari 2021, hlm 77-97

kebingungan dan kebingungan melalui spekulasi dan penyebaran informasi palsu. Sebagai contoh, Presiden Trump memuji potensi obat klorokuin untuk melawan virus corona baru. Seperti dilaporkan di CNN, "Pejabat kesehatan di Nigeria telah mengeluarkan peringatan tentang klorokuin setelah mereka mengatakan tiga orang di negara itu overdosis pada obat itu, setelah komentar Presiden Trump tentang menggunakannya untuk mengobati coronavirus" (Busari dan Adebayo 2020).

\section{Wacana Perbaikan Citra}

Wacana perbaikan citra adalah pesan persuasif atau sekelompok pesan yang merespons serangan atau kecurigaan yang mendorong sikap negatif tentang sumber perbaikan citra (W. L. Benoit, 1997). Seperti yang baru saja disebutkan, ancaman terhadap suatu citra memiliki dua komponen: menyalahkan dan menyinggung (Pomerantz, 1978). Dua elemen ini sesuai dengan konsep Fishbein dan Ajzen (Fishbein \& Ajzen, 2010) tentang keyakinan (menyalahkan) dan nilai-nilai (offensiveness) seseorang dapat menanggapi serangan (atau kecurigaan) dengan menolak atau mengurangi tanggung jawab (mengubah keyakinan tentang kesalahan) atau mengurangi serangan (mengubah nilai). Dimungkinkan juga untuk mengakui kesalahan dan meminta maaf; seseorang juga dapat mengusulkan untuk memperbaiki masalah atau mencegahnya terjadi lagi. Pendekatan-pendekatan ini dapat ditempuh dengan pesan persuasif yang menciptakan atau mengubah keyakinan atau nilai-nilai audiens (atau persepsi mereka tentang kesalahan dan penyerangan).

Memahami bahwa ancaman terhadap citra seseorang terdiri dari kesalahan (kepercayaan) dan ofensif (nilai) berarti bahwa kita dapat menggunakan teori tindakan beralasan Fishbein dan Ajzen untuk mengembangkan gagasan untuk membujuk audiens atau memperbaiki citra seseorang. Dimulai dengan gagasan bahwa suatu sikap didasarkan pada pasangan nilai / keyakinan yang menonjol. Benoit dan Benoit (W. Benoit \& Benoit, 2008) menawarkan enam saran untuk meningkatkan sikap berdasarkan pada teori ini yakni (1) Memperkuat keyakinan yang terkait dengan sikap yang menguntungkan. (2). Memperkuat nilai yang terkait dengan sikap yang menguntungkan. (3). Melemahkan keyakinan yang terkait dengan sikap yang tidak menguntungkan. (4). Melemahkan nilai yang terkait dengan sikap yang tidak menguntungkan. (5). Ciptakan sikap baru yang menyenangkan. (6) Ingatkan hadirin tentang sikap positif yang dilupakan. 
Jurnal Ilmu Komunikasi UHO : Jurnal Penelitian Kajian Ilmu Komunikasi dan Informasi.

Volume 6, No. 1, Januari 2021, hlm 77-97

Teori pemulihan citra Benoit (W. L. Benoit, 1995) diterapkan untuk menganalisis strategi pesan kampanye. Teori ini berpendapat bahwa ada lima opsi umum yang tersedia untuk pertahanan diri: penolakan, menghindari tanggung jawab, mengurangi pelanggaran, tindakan korektif, dan malu/aib/kedermawan. Benoit mencatat, setidaknya ada lima strategi dasar di dalam image restoration theory ini, yaitu: Pertama, Denial atau penyangkalan. Strategi seperti bisa dilihat di kalangan politisi, yang sering melakukan penyangkalan (simple denial). Ada pula yang mengalihkan kesalahan kepada orang lain (shifting the blame). Kedua, Evading of Responsibility. Strategi ini adalah menghindari tanggungjawab atas pekerjaan atau tindakannya, tujuannya untuk mengurangi tanggungjawab atas konsekuensi tindakannya (kesalahan) tersebut. Dalam strategi kedua ini, ada beberapa langkah yang bisa ditempuh seperti Provocation (pengakuan bahwa hal tersebut dilakukan karena terpancing oleh suatu hal), Defeasibility (pengakuan bahwa hal tersebut dilakukan karena kekurangan informasi dan kemampuan yang cukup), Accident (pengakuan bahwa semua hal terjadi karena karena tidak terduga), Good Intention (pengakuan bahwa semuanya berawal dari niat yang baik, sama sekali tidak ada maksud untuk membuat kesalahan).

Ketiga, Reducing Offensiveness of Event. Dalam strategi ini, dikondisikan bahwa pihak yang melakukan kesalahan pantas diberikan keringanan. Caranya adalah dengan mengutip tindakan-tindakan positif yang sudah dilakukan di masa lalu dan bisa diterima publik dengan baik (Bolstering). Bisa juga melakukan upaya-upaya yang bisa mengurangi perasaan negatif dengan cara-cara persuasi kepada publik, sekaligus meyakinkan publik bahwa yang terjadi tidaklah seburuk seperti yang dipikirkan, dipersepsikan, atau yang terjadi (minimization). Cara yang lainnya adalah dengan membuat perbedaan perlakuan atas kesalahan yang dilakukan dengan yang dilakukan orang lain yang juga melakukan hal yang sama (differensiasi). Bisa juga dengan membandingkan suatu kejadian tetapi dalam konteks yang berbeda (trancendence). Ada juga attack accuser, yaitu menyerang kredibilitas yang menuduh, dengan mempertanyakan kompetensi dan hal lainnya, dan perhatian publik pun berpindah ke penuduh. Compensation, adalah memberikan ganti rugi sebaggai bentuk tanggungjawab atau menebus kesalahan yang terjadi, sehingga perbuatan diampuni dan reputasi balik menjadi baik.

Keempat, Corrective Action. Strategi ini dilakukan dengan cara menjanjikan bahwa tindakan (kesalahan) yang terjadi akan diperbaiki lebih baik lagi ke depannya. Dengan janjijanji yang meyakinkan, diharapkan citra positifnya kembali lagi. Kelima, Mortification. 
Jurnal Ilmu Komunikasi UHO : Jurnal Penelitian Kajian Ilmu Komunikasi dan Informasi.

Volume 6, No. 1, Januari 2021, hlm 77-97

Strategi ini sangat elegan, yaitu mengakui kesalahan, dan dengan jelas meminta pengampunan atas tindakan yang dilakukan.

\section{METODE PENELITIAN}

Studi ini menggunakan metode kritik retoris, yang membantu memahami bagaimana orang menggunakan simbol untuk saling mempengaruhi. Kritik retoris bukan sebagai masalah kritis atau menyerang retorika, melainkan sebagai proses analisis, interpretasi, dan evaluasi penggunaan bahasa persuasif.(Campbell \& Burkholder, 1997). Kritik retoris adalah "proses sistematis untuk menerangi dan mengevaluasi" pesan persuasif (Andrews \& Terrill, 1998). Tidak seperti analisis isi, kritik retoris meneliti hubungan konteks dan pesan. Kritik retoris juga dapat membuat penilaian tentang pentingnya unsur-unsur pesan sebagai gestalt yang menganggap tidak hanya frekuensi sederhana tetapi juga menonjol seperti yang ditunjukkan oleh penempatan, pengembangan, dan hubungan ide dalam pesan persuasif.

Sumber data dalam penelitian ini adalah konten youtube Mata Najwa tanggal 24 April 2020 yang memuat wawancara khusus dengan Presiden Jokowi dengan judul Jokowi Diuji Pandemi. Pertama kami mengidentifikasi tuduhan yang secara langsung disampaikan atau ditanyakan oleh Najwa Shihab dalam acara tersebut, kemudian kami mengidentifikasi strategi pesan yang digunakan dalam menjawab tuduhan terhadap pemerintah terkait dengan COVID19.

\section{HASIL DAN PEMBAHASAN}

Secara umum strategi pesan yang disampaikan Presiden Jokowi dalam dialog dengan Najwa Shihab tanggal 21 April 2020 menjawab beberapa kritikan yang disampaikan publik terkait penanganan COVID-19 di Indonesia. Dialog ini dibagi ke dalam lima bagian yang menjawab berbagai tuduhan yang dialamatkan kepada pemerintah. Tuduhan dan strategi pemulihan citra pemerintah yang disampaikan Jokowi dalam dialog tersebut, dapat dilihat dalam tabel berikut: 
Jurnal Ilmu Komunikasi UHO : Jurnal Penelitian Kajian Ilmu Komunikasi dan Informasi.

Volume 6, No. 1, Januari 2021, hlm 77-97

\section{Tabel 1 Kritikan dan Strategi Pemulihan Citra Jokowi Berdasarkan Teori Restorasi Citra Benoit}

\begin{tabular}{ll}
\hline \multicolumn{1}{c}{ Tuduhan/Kritikan } & \multicolumn{1}{c}{ Stategi } \\
\hline Pemerintah tidak Transparan & Penyangkalan, serang penuduh, niat baik. \\
\hline Lamban Tangani COVID 19 & Diferensiasi, Defeasibility \\
\hline PSBB Tidak Tegas & Diferensiasi, Penyangkalan, Niat Baik \\
\hline Kebijakan Tidak Sinkron & $\begin{array}{l}\text { Difeasibility, tindakan perbaikan, diferensiasi, } \\
\text { memperkuat, provokasi }\end{array}$ \\
\hline Larangan Mudik Tidak Tegas & Diferensiasi, Penyangkalan \\
\hline Pra Kerja Bermasalah & Kecelakan, Niat baik \\
\hline
\end{tabular}

Analisis retoris dibagi menjadi beberapa bagian untuk setiap tuduhan dan tanggapan Jokowi menjadi strategi tipologi teori restorasi citra Benoit.

\section{Tuduhan 1: Pemerintah tidak transparan soal data COVID-19}

\section{Penyangkalan}

Pemerintah menyangkal tuduhan bahwa pemerintah tidak transparan soal data COVID-19. Presiden Jokowi menyampaikan bahwa semua data yang diumumkan pemerintah adalah konsolidasi dari data daerah mulai dari kabupaten, kota dan provinsi. Kalau ingin melihat silahkan dilihat langsung dari data-data di daerah. "Misalnya daerah A, a.covid.go.id, b.corona.go.id mereka punya semua kok." Jokowi menyampaikan perlunya kehati-hatian pemerintah dalam menyampaikan informasi ke lapangan. Menurutnya, informasi yang disampaikan tidak boleh membuat masyarakat panik. (Shihab, 2020d)

Sebelumnya Jokowi sempat menyatakan, transparansi data terkait virus Corona mengandung akibat buruk karena bisa menimbulkan kepanikan warga. Kini, Jokowi menilai data Corona perlu dibuka ke publik. Sebetulnya dulu pihaknya inginnya menyampaikan, tapi juga berhitung mengenai kepanikan dan keresahan di masyarakat, juga efek nantinya pada pasien apabila sembuh.(detikcom, 2020). "Karena kalau panik sistem kesehatan nasional kita tidak mampu menangani itu karena semua orang akan berbondong-bondong minta diperiksa ke rumah sakit." "Saya sampaikan transparan supaya semua orang mengerti. Tes uji secara massif, pelacakan yang progresif, isolasi yang ketat." (Shihab, 2020d)

\section{Serang Penuduh}

Jokowi juga menjawab tudingan IDI dengan meminta IDI membuka saja data kematian jika IDI memang memiliki data itu. Sampaikan aja ke Gugus Tugas, Kemenkes yang seribu itu ada dimana, karena sekarang ini kalau sakit gejala demam, batuk, pasti protokol kesehatannya membungkus yang meninggal itu dengan protokol COVID. "Tapi 
Jurnal Ilmu Komunikasi UHO : Jurnal Penelitian Kajian Ilmu Komunikasi dan Informasi.

Volume 6, No. 1, Januari 2021, hlm 77-97

tidak disampaikan ke publik yang justru memperkeruh. Posisi yang sekarang bukan posisi yang mudah. Sampaikan saja datanya, kalau datanya pasti dimasukkan ke dalam konsolidasi data yang ada." (Shihab, 2020d)

Di samping itu Jokowi juga mempertanyakan di bagian mana pemerintah tidak transparan soal data COVID-19. "Yang tidak terbuka di sebelah mana? Data itu kita konsolidasi dari kabupaten, kota, provinsi, mereka punya semua. Apa yang tidak terbuka, Dulu dia meminta data terkait COVID disampaikan secara hati-hati karena tidak ingin terjadi kepanikan. Karena jika terjadi kepanikan maka sistem kesehatan nasional tidak mampu menangangi hal itu karena akan banyak warga yang ke rumah sakit minta diperiksa. Menurut Jokowi transparansi diperlukan agar semua orang mengerti dan bisa menjaga bisa memproteksi lingkungannya, siapa yang terkena sehingga memahami tindakan apa yang akan dilakukan. "Jadi perlu dilakukan tes uji secara massif, pelacakan yang agresif, dan isolasi yang ketat, jadi data yang transparan berhubungan dengan hal itu.'(Shihab, 2020d)

\section{Tuduhan 2: Lamban Tangani COVID-19}

Dalam wawancara dengan Presiden Jokowi, Najwa Shibab menanyankan soal ada anggapan bahwa pemerintah lamban menangani COVID-19, dan juga tuduhan bahwa aparat pemerintah menganggap bahwa virus ini hanya flu biasa. Menjawab hal ini Jokowi menggunakan strategi sebagai berikut:

\section{Diferensiasi}

Presiden Jokowi mengatakan bahwa virus ini adalah virus yang berbahaya. Namun demikian virus ini bisa dicegah dan dihindari. Kuncinya ada pada kedisplinan warga masyarakat untuk menjaga jarak, memakai masker, dan mencuci tangan serta menghindari kerumunan. Menurut Jokowi pihaknya tidak ingin membuat keputusan yang terkesan mendadak atau grusa-grusu yang bukan menyelesaikan masalah tapi justru menimbulkan masalah baru.

Ini virus yang sangat berbahaya, tapi bisa dicegah dan dihindari. Tapi kita tidak ingin membuat kebijakan dengan cara grusa-grusu. Yang ini dinilai oleh publik itu mungkin lamban di situ. Membuat publik tenang itu tidak dilihat sebagai sebuah keputusan. Itu sebuah keputusan. Membuat publik tidak panik. Itu keputusan. Itu tidak dilihat sebagai keputusan. Agak berbedanya di situ.(Shihab, 2020b)

Jokowi menyampaikan dulu lab yang dimilki Indonesia diragukan tidak bisa tes PCR padahal pihaknya sudah menguji berulang kali dan bisa. "Kita uji bolak-balik bisa. Sampai 
Jurnal Ilmu Komunikasi UHO : Jurnal Penelitian Kajian Ilmu Komunikasi dan Informasi.

Volume 6, No. 1, Januari 2021, hlm 77-97

sekarang tidak ada masalah. Permasalahan PCR, APD, masker, ada 213 negara yang terpapar memperebutkan ini."(Shihab, 2020b)

\section{Defeasibility}

Di awal wawancara Jokowi menegaskan pihaknya mengutamakan penangangan kesehatan daripada sektor lainnya. Meski diakui bahwa sektor lain seperti ekonomi juga ikut menjadi perhatian pemerintah. Terkait dengan kinerja kinerja Menteri Kesehatan dr Terawan Agus Putranto yang dinilai publik tidak maksimal, Jokowi memahaminya, namun demikian dia melihat Terawan sudah bekerja keras untuk menangani wabah ini.

Tidak ada yang sempurna. Kalau ada yang kecewa itu wajar. Setiap pekerjaan ada yang menilai. Setiap keputusan ada resikonya. Yang ditangani Menkes itu bukan hanya COVID-19. Ada juga demam berdarah yang baru ramai di beberapa provinsi dan penyakit-penyakit lainnya. Dan saya melihat $d r$ Terawan bekerja sangat keras.(Shihab, 2020b)

\section{Tuduhan 3: Pembatasan Sosial Berskala Besar (PSBB) Tidak Tegas Diferensiasi}

Jokowi tak bisa memungkiri bahwa setelah diberlakukan PSBB di beberapa daerah, pasar, jalan dan beberapa fasilitas umum masih ramai. Sebaliknya, ia menggunakan diferensiasi untuk menanggapi tuduhan ini.

Saya melihat di lapangan pasar masih ramai. Kemudian saya kemarin baru muter di Jakarta bagian utara terminal masih ramai, kemudian di Bogor saya melihat juga mirip-mirip sama. Artinya apa, ya sebetulnya aktivitas, mobilitas itu yang harus dikurangi. Tetapi aktivitas bisa dilakukan tetapi jaga jarak. Penting sekali jaga jarak, yang namanya pakai masker itu sangat penting, jauhi kerumunan penting sekali, dan Memperkuat setiap kegiatan apapaun habis itu cuci tangan itu penting. (Shihab, 2020b)

Ketika ditanya Najwa apakah dengan kondisi kedisipinan warga menerapkan protokol kesehatan yang tidak maksimal selama ini, pemerintah akan memberlakukan sanksi tegas berupa hukuman atau denda, Jokowi menggunakan strategi memperkuat pesan sebelumnya. "Instrumen di lapangan yang kita gunakan TNI dan Polri, awal-awal menegur, dalam transisi, memberi tahu, tetapi jika dianggap belum cukup ya mungkin ada step berikutnya."(Shihab, 2020b). Saat ditanya apakah nanti bisa berwujud sanksi tegas dari pemerintah. Jokowi memberikan jawaban untuk memperkuat jawaban sebelumnya. "Ya kalau nanti dalam sosialisasi sudah cukup dan di lapangan belum ada perbaikan bisa saja kita masuk ke sana."(Shihab, 2020b) 
Jurnal Ilmu Komunikasi UHO : Jurnal Penelitian Kajian Ilmu Komunikasi dan Informasi.

Volume 6, No. 1, Januari 2021, hlm 77-97

\section{Niat Baik}

Ketika ditanya Najwa tentang warga yang melanggar kebijakan PSBB karena butuh untuk biaya hidup sehingga mengabaikan protokol kesehatan, Jokowi memakai strategi niat baik dalam menjawab hal tersebut. "Ya itu memang pilihan-pilihan semua tidak enak. Dan kita menyadari di luar itu masih banyak buruh harian, pekerja harian, dan ini menjadi kalkulasi kita jangan sampai kita ingin menyelesaikan masalah malah muncul masalah baru.'(Shihab, 2020b)

\section{Penyangkalan}

Saat ditanya mengapa pemerintah tidak mengambil kebijakan karantina wilayah seperti yang tertuang di dalam undang-undang atau disarankan beberapa pihak, apakah karena pemerintah tidak cukup uang untu melaksanakan kebijakan itu, Jokowi menjawab dengan strategi penyangkalan.

Karantina Wilayah itu kan sama dengan lockdown. Artrinya masyarakat hanya diam di rumah. Bus berhenti, taksi berhenti, ojek berhenti, pesawat berhenti, MRT berhenti hanya di rumah. Untuk Jakarta saja pernah kami hitung lebih kurang 550 miliar per hari. Kalau Jabodetabek tiga kali lipat. Bukan masalah budget, kita kan juga belajar dari negara-negera lain, apakah lockdown berhasil menyelesaikan masalah, kan tidak? Coba tunjukkan negara mana yang berhasil melakukan lockdown dan bisa menghentikan masalah ini, gak ada menurut saya.(Shihab, 2020b)

Jokowi mengaku setiap hari selalu ada briefing kertas memuat negara-negara yang terinfeksi COVID-19. Jokowi menilai dalam memutuskan sesuatu setiap negara-negara berbeda. Karena negara-negara itu berbeda tingkat kedisiplinan berbeda, kemampuan fiscal yang berbeda. "Jadi gak bisa suruh niru-niru negara-negara lain. Sampai saat ini saya melihat tidak ada formula yang pasti untuk menyelesaikan masalah ini.”(Shihab, 2020b)

Namun demikian Jokowi kemudian juga menyampaikan bahwa disiplin warga dalam menjalankan protokol kesehatan menjadi kunci menyelesaikan masalah ini. "Ya oleh sebab itu saya sampaikan, tingkat kedisiplinan itu sangat menentukan. Kalau kita melakukan ini dengan disiplin yang kuat, itu yang akan mengurangi dan bisa menyelesaikan masalah ini dengan segera."(Shihab, 2020b)

\section{Tuduhan 4: Kebijakan Tidak Sinkron}

Salah satu persoalan yang disorot Najwa Shihab dalam wawancara dengan Jokowi juga adalah tidak sinkronnya peraturan yang disusun kementerian satu dengan yang lain serta antara pemerintah pusat dan pemerintah daerah. Mengenai hal ini Presiden Jokowi menjawab dengan strategi 
Jurnal Ilmu Komunikasi UHO : Jurnal Penelitian Kajian Ilmu Komunikasi dan Informasi.

Volume 6, No. 1, Januari 2021, hlm 77-97

\section{Defeasibility}

Presiden Jokowi menjawab dengan mengakui bahwa kinerja kementeriannya masih perlu diperbaiki terutama terkait dengan kebijakan penanganan COVID-19.

Ya tidak ada hal yang sempurna. Saya kira yang selalu saya evaluasi mana yang kurang saya perintahkan untuk selalu diperbaiki. Plus minusnya mana yang baik itu yang dipakai. Pemerintah tidak bisa bekerja sendirian. Pemerintah pusat tidak bekerja sendirian. Harus melibatkan provinsi, kabupaten/kota, tidak mungkin bekerja sendirian.'(Shihab, 2020b)

\section{Tindakan Perbaikan}

Ketika terjadi perbedaan Peraturan Menteri Kesehatan dan Peraturan Menteri Perhubungan soal larangan ojek online beroperasi di masa PSBB di Jakarta. Jokowi mengaku melakukan tindakan perbaikan dengan mengundang kedua menteri untuk diminta klarifikasi.

Saya undang, Menteri saya undang dan disampaikan kenapa dibolehkan oleh Kementerian Perhubungan. Menteri menyampaikan pada saya wong tidak dilarang pun mereka sudah sepi penumpang. Kalau dilarang nanti jadi masalah yang baru. Tapi ada yang melihat dari sudut kesehatan ada yang melihat dari sudut ekonomi Diferensiasi sehinga perlu disinkronkan."(Shihab, 2020b)

Najwa Shihab juga memberikan pertanyaan untuk mendalami ke arah mana kebijakan pemerintah dalam penanganan COVID-19 apakah prioritasnya kesehatan atau ekonomi. Menjawab hal tersebut Jokowi menyampaikan bahwa yang diutamakan adalah kesehatan, tetapi antara kesehatan dan ekonomi ada relevansinya sehingga tidak mungkin dihilangkan salah satunya.

"Hanya yang didahulukan yang mana. Oleh sebab itu kesehatan adalah yang diutamakan tetapi ini berhubungan. Coba saya berikan contoh. Kalau ekonomi gak baik, atau yang lebih buruk lagi masyarakat tidak makan, maka imunitas menjadi lemah, virusnya gampang sekali masuk. Ini berhubungan ada relevansi. Gak bisa ditinggalkan gak bisa.'(Shihab, 2020b)

Saat ditanya Najwa meski kedua aspek kesehatan dan ekonomi penting ada keputusan yang harus diambil, Jokowi menjawab bahwa dalam penanganan kasus COVID-19 pemerintah tidak punya pilihan yang tidak beresiko. "Ya itu pilihan-pilihan yang diambil buruk semua. Kalau ada pilihan yang baik dan buruk bisa dipilih. Gak akan memuaskan semua orang karena pilihannya buruk-buruk semua."(Shihab, 2020b)

Jokowi juga mengakui bahwa kabinetnya masih berpikir sektoral. Namun demikian dia juga memaklumi karena memang didesak oleh sektornya masing-masing.

"Saya melihat memang masih sektoral. Setiap kementerian pasti akan melihat kepentingan sektornya masing-masing. Itu yang terus saya tekankan agar ini satu 
Jurnal Ilmu Komunikasi UHO : Jurnal Penelitian Kajian Ilmu Komunikasi dan Informasi.

Volume 6, No. 1, Januari 2021, hlm 77-97

bahasa. Utamakan kesehatan dulu. Tapi dalam prakteknya mereka didesak oleh sektornya masing-masing yang menunjukkan bahwa sektor ini kalau tidak diberikan perhatian akan memberikan dampak ini dampak ini. Sehingga menteri kadangkadang atau daerah pun kadang juga berbeda itu karena suaranya itu di lapangan itu berbeda." (Shihab, 2020a)

\section{Memperkuat}

Jokowi memakai strategi memperkuat saat ditanya Najwa bahwa komando ada di tangan presiden dalam penanganan COVID-19.

"Ya selalu, selalu kalau ada masalah di lapangan seperti itu, langsung detik itu juga saya panggil. Kalau alasannya masuk akal dan alasannya memang untuk kepentingan rakyat banyak ya saya putuskan. Tetapi memang sering kita diberikan pilihan yang buruk-buruk semuanya. Sehingga yang diputuskan manapun celah untuk Provokasi mendapatkan resiko dari pihak lain atau sektor yang lain pasti ada."(Shihab, 2020b)

Terkait dengan kebijakan Menteri Perhubungan yang tetap mengoperasikan Kereta Rel Listrik (KRL) selama masa pandemi, sementara surat dari Kepala Daerah Jabodetabek meminta dihentikan sementara karena menimbulkan kerumunan dan berpotensi menjadi klaster penyebaran COVID-19, Jokowi menggunakan strategi provokasi atau pengakuan bahwa hal tersebut dilakukan karena terpancing oleh suatu hal. Jokowi mengatakan jika daerah mau mempersiapkan dan mau menanggung dari keputusan yang diminta itu pihaknya akan menghentikan KRL. "Artinya pekerja harian, buruh-buruh harian, pedagang asongan yang mendapatkan nafkah dari naik KRL karena naik KRL itu ditanggung oleh mereka, dijamin oleh mereka dengan bantuan sosial yang baik saya hentikan.” (Shihab, 2020a)

Najwa menanyakan artinya tanggung jawab ada di pemerintah daerah. Jokowi menjawab karena daerah yang meminta maka mereka yang harus bertanggung jawab.

"Karena kan mereka meminta. Mestinya disiapkan bantalan sosial, jaring pengaman sosialnya disiapkan dulu. Jangan hanya meminta dihentikan kemudian ya sudah masyarakat disuruh cari sendiri-sendiri gak bisa seperti itu, itu yang saya nggak bisa. Bukan masalah kebijakannya, tidak bukan itu, ndak apa-apa. Siapkan dulu bantalan sosial untuk mereka atau kalau tidak ada bus siapkan bus, siapkan bus, agar tidak berdesakan, Tapi busnya diisi separoh saja sehingga ada phisycal distancing di situ. Sehingga ini memberikan solusi. Kalau kebijakan tidak memberikan solusi, itu akan memunculkan masalah baru.'(Shihab, 2020b) 
Jurnal Ilmu Komunikasi UHO : Jurnal Penelitian Kajian Ilmu Komunikasi dan Informasi.

Volume 6, No. 1, Januari 2021, hlm 77-97

\section{Tuduhan 5: Larangan Mudik Tidak Tegas}

\section{Diferensiasi}

Mengenai larangan mudik. Jokowi juga memberikan jawaban yang bernada diferensiasi. Dia mengakui bahwa ada pro kontra di kabinetnya mengenai kebijakan mudik tahun 2020 .

"Semua kementerian pro dan kontra. Ada yang setuju ada yang tidak setuju. Tetapi saya sampaikan suatu saat akan saya larang. Karena kita tahu bahwa yang ingin mudik masih menyangkut orang yang jutaan ada 34 persen yang masih ingin mudik. Ini angka yang tinggi sekali." (Shihab, 2020a)

Ketika ditanya kenapa tidak dilarang saja secara langsung oleh pemerintah, Jokowi menyatakan bahwa pihaknya menilai harus ada masa transisi.

"Ya kita kan kemarin memakai ada transisinya. Sehingga jangan sampai meninmbulkan shock dan justru memunculkan masalah baru. Rame-rame nanti ke stasiun, bandara, ke terminal. Yang terjadi justru terjadi penumpukan orang di suatu tempat, yang itu justru tidak menyelesaikan masaah tetapi memunculkan masalah baru penularan yang nanti akan menyebar."(Shihab, 2020a)

\section{Penyangkalan}

Saat Jokowi ditanya oleh Najwa bahwa masalah yang ditakutkan akan terjadi gelombang orang yang mudik dalam jumlah besar sudah terjadi berdasarkan data Kementerian Perhubungan sudah hampir 1 juta orang atau sudah 900 ribu orang yang sudah mudik dan tersebar di daerah. Jokowi menyangkal bahwa itu adalah kegiatan mudik. "Kalau itu bukan mudik, itu pulang kampung. Di sini sudah tidak bekerja, anak istrinya ada di kampung. Kalau mudik itu ya di hari lebarannya.(Shihab, 2020a)"

Jokowi menyatakan daripada tinggal di Jakarta tidak bekerja lebih baik mereka pulang kampung.

"Coba dilihat di lapangan di Jakarta mereka menyewa ruang 3x4 di sini isinya 9- 8 orang. Mereka di sini tidak bekerja, lebih berbahaya mana, di sini dihuni 9-8 orang. Atau pulang ke kampung tapi di sana juga disiapkan isolasi dulu oleh desa saya kira sekarang semua desa sudah menyiapkan isolasi ini. Lebih bahaya mana? Saya kira kita harus melihat lebih detail lapangannya lebih detail angka-angkanya."(Shihab, 2020a)

Jokowi mengatakan pihaknya melakukan pelarangan mudik secara bertahap untuk menghindari kerumunan di bandara, terminal, stasiun kereta api, dan pelabuhan. "Tahapan pertama, ASN, TNI, Polri, Pegawai BUMN dilarang mudik. Nah ini kan tinggal pada suatu titik kita juga akan melarang semua masyarakat sama tidak mudik."(Shihab, 2020a) 
Jurnal Ilmu Komunikasi UHO : Jurnal Penelitian Kajian Ilmu Komunikasi dan Informasi.

Volume 6, No. 1, Januari 2021, hlm 77-97

\section{Tuduhan 6: Kartu Pra Kerja Bermasalah}

\section{Kecelakaan}

Najwa menyinggung beberapa masalah yang berkaitan dengan Kartu Pra Kerja salah satunya adalah bahwa warga masyarakat saat ini tidak butuh pelatihan sebagaimana yang dilakukan dalam program Kartu Pra Kerja, tetapi butuh uang untuk makan. Menanggapi hal ini Jokowi memakai strategi melakukan penghindaran tanggungjawab atas pekerjaan atau tindakannya, tujuannya tentu juga untuk mengurangi tanggungjawab atas konsekuensi tindakannya (kesalahan) tersebut. Adapun bagian dari pengurangan tanggung jawab yang digunakan adalah accident yakni pengakuan bahwa semua hal terjadi karena karena tidak terduga.

"Ya memang awal Kartu Pra Kerja untuk pelatihan. Kita memang menyiapkan pelatihan mengenai teknisi coding, programming, pelatihan barista, pelatihan cheff, tapi ada kondisi ekstraordinary maka desainnya diubah total karena sebenarnya harusnya pelatihan barista harus ketemu, tetapi kemudian diubah total menjadi online."(Shihab, 2020c)

Jokowi menyatakan bahwa memang program Kartu Pra Kerja sudah diubah dari murni training tetapi ini sudah semi bansos, sehingga 600 ribu selama 4 bulan itu semi bansos. Terutama korban PHK, hampir 80-90 persen yang ikut program ini adalah korban PHK.(Shihab, 2020c)

\section{Niat Baik}

Terkait dengan dana pelatihan yang mencapai 1 juta rupiah. Jokowi menilai bahwa ada 1 juta untuk pelatihan. Itu bukan itu, ini adalah program yang terbuka, semua artinya semua perusahaan bisa menawarkan pelatihan online.

“Biayanya juga tidak semua 1 juta. Ada yang 180 ribu, ada yang 800 ribu ada yang 200 ribu juga ada tinggal memilih kok tergantung pelatihan yang diinginkan. Misalnya ada perusahaan A menawarkan pelatihan di situ belum tentu dipilih oleh pengguna atau peserta Pra Kerja." (Shihab, 2020c)

\section{Implikasi}

Penanganan pandemi virus corona yang dilakukan pemerintahan Presiden Joko Widodo mendapatkan sentimen negatif dari netizen. Hal itu berdasarkan analisis terbaru Institute for Development of Economics and Finance (Indef). Sebagian besar responden memiliki sentimen negatif, mulai dari Pembatasan Sosial Berskala Besar, pembebasan narapidana, larangan mudik dan sebagainya. Kebijakan mengenai Pembatasan Sosial Berskala Besar (PSBB) mendapatkan sentimen negatif 79 persen, pembebasan napi 46 persen, ketidaktegasan larangan mudik 54 persen, jaring pengaman sosial 56 persen, kartu 
Jurnal Ilmu Komunikasi UHO : Jurnal Penelitian Kajian Ilmu Komunikasi dan Informasi.

Volume 6, No. 1, Januari 2021, hlm 77-97

prakerja 81 persen, dan pengangguran akibat COVID-19 sebesar 84 persen. Hanya kebijakan pembebasan tarif listrik yang mendapatkan sentimen positif yakni sebesar 94 persen. Presiden Jokowi menempati posisi teratas paling banyak diperbincangkan yakni 22.574 perbincangan dengan sentimen negatif 68 persen.(CNN Indonesia, 2020b)

Meskipun jajak pendapat tidak berusaha untuk memastikan penyebab penurunan citra ini, tuduhan yang digambarkan di atas berkontribusi pada masalah citra pemerintah. Karena itu, kami berpendapat bahwa citra pemerintah mengalami penurunan dari dua tuduhan utama. Pertama, ia gagal mengatasi sebaran wabah COVID-19 karena warga terinfeksi selalu bertambah setiap hari. Kedua, tidak serius dalam mengeksekusi kebijakan yang telah diambil, karena peraturan yang terus berubah dan tumpang tindih satu sama lain.

\section{SIMPULAN}

Berdasarkan hasil kajian dapat disimpulkan pemerintah Jokowi senantiasa berupaya untuk memoles citranya dengan menjawab berbagai tuduhan atau kritik yang dilayangkan berbagai pihak terkait dengan penanganan COVID 19 di Indonesia. Tuduhan yang dijawab itu antara lain pemerintah tidak transparan terkait data COVID-19, Jokowi menjawab dengan strategi penyangkalan, serang penuduh, dan niat baik. Terkait dengan penangangan COVID19 yang dinilai lamban, Jokowi menjawab dengan strategi diferensiasi dan defeasibility. Terkait dengan kritik soal PSBB tidak tegas, Jokowi menjawab dengan memakai strategi Diferensiasi, Penyangkalan, Niat Baik, sedangkan terkait dengan kebijakan yang tidak sinkron, Jokowi memakai strategi Difeasibility, tindakan perbaikan, diferensiasi, memperkuat, provokasi. Persoalan larangan mudik yang tidak tegas, Jokowi menjawab dengan strategi diferensisasi dan penyangkalan, sedangkan tentang pra kerja yang dianggap bermasalah, Jokowi menggunakan strategi kecelakaan dan niat baik.

Dari hal tersebut terlihat bahwa Jokowi dalam perbaikan citra pemerintah cenderung memakai strategi bertahana yakni memperbanyak strategi diferensiasi dan defeasibility, serta niat baik. Meski ada penyangkalan tetapi Jokowi juga menghindari menyerang para penuduhnya. 
Jurnal Ilmu Komunikasi UHO : Jurnal Penelitian Kajian Ilmu Komunikasi dan Informasi.

Volume 6, No. 1, Januari 2021, hlm 77-97

\section{DAFTAR PUSTAKA}

Andrews, J. R. ,. Leff, M. C., \& Terrill, R. (1998). Reading rhetorical texts: An introduction to criticism. Houghton Mifflin Co.

Argenti, P. A. (2020, March 13). Communicating Through the Coronavirus Crisis. Harvard Business Review. https://hbr.org/2020/03/communicating-through-the-coronaviruscrisis

Benoit, W., \& Benoit, P. (2008). Persuasive Messages: The Process of Influence. Wiley. https://books.google.co.id/books?id=qafZAAAAMAAJ

Benoit, W. L. (1995). Sears' repair of its auto service image: Image restoration discourse in the corporate sector. Communication Studies, 46(1-2), 89-105. https://doi.org/10.1080/10510979509368441

Benoit, W. L. (1997). Image repair discourse and crisis communication. Public Relations Review, 23(2), 177-186. https://doi.org/10.1016/S0363-8111(97)90023-0

Benoit, W. L. (2015). Accounts, excuses, and apologies: Image repair theory and research (Second edition). SUNY Press.

Benoit, W. L., \& Brinson, S. L. (1999). Queen Elizabeth's image repair discourse: Insensitive royal or compassionate queen? Public Relations Review, 25(2), 145-156. https://doi.org/10.1016/S0363-8111(99)80159-3

Bernie, M. (2020a). Program Kartu Prakerja Jalan Terus Meski Dikritik Habis-habisan. tirto.id. $\quad \mathrm{https} / /$ tirto.id/program-kartu-prakerja-jalan-terus-meski-dikritik-habishabisan-ePZa

Bernie, M. (2020b). Survei Cyrus Network: Penonton Mata Najwa Lampaui ILC TvOne. tirto.id. https://tirto.id/survei-cyrus-network-penonton-mata-najwa-lampaui-ilc-tvone$\mathrm{eEPz}$

Bramasta, D. B. (2020). IDI Sebut Angka Kematian Terkait Corona di Indonesia Lebih dari 1.000 Kasus Halaman all. KOMPAS.com. https://www.kompas.com/tren/read/2020/04/19/112918065/idi-sebut-angka-kematianterkait-corona-di-indonesia-lebih-dari-1000-kasus

Campbell, K. K., \& Burkholder, T. . R. (1997). Critique of contemporary rhetoric (2nd ed.). Wadsworth.

CNN Indonesia. (2020a). Kekacauan Bansos Corona, Masalah Klasik Big Data. nasional. https://www.cnnindonesia.com/nasional/20200508133813-20-501305/kekacauanbansos-corona-masalah-klasik-big-data

CNN Indonesia. (2020b). Netizen Respons Penanganan Covid-19 Pemerintahan Jokowi. teknologi. https://www.cnnindonesia.com/teknologi/20200426131139-192497384/netizen-respons-penanganan-covid-19-pemerintahan-jokowi

Coombs, W. T., \& Holladay, S. J. (Eds.). (2010). The handbook of crisis communication. Wiley-Blackwell.

COVID-19, G. T. P. P. (2020). Peta Sebaran | Gugus Tugas Percepatan Penanganan COVID-19. Covid19.Go.Id. https://covid19.go.id/peta-sebaran

detikcom, T. (2020). Saat Jokowi Tak Ingin Dianggap Tertutup soal Data Corona. detiknews. https://news.detik.com/berita/d-4984637/saat-jokowi-tak-ingin-dianggaptertutup-soal-data-corona

DiStaso, M. W., Vafeiadis, M., \& Amaral, C. (2015). Managing a health crisis on Facebook: How the response strategies of apology, sympathy, and information influence public relations. Public Relations Review, 41(2), 222-231.

https://doi.org/10.1016/j.pubrev.2014.11.014 
Jurnal Ilmu Komunikasi UHO : Jurnal Penelitian Kajian Ilmu Komunikasi dan Informasi.

Volume 6, No. 1, Januari 2021, hlm 77-97

Drumheller, K., \& Benoit, W. L. (2004). USS Greeneville collides with Japan's Ehime Maru: Cultural issues in image repair discourse. Public Relations Review, 30(2), 177-185. https://doi.org/10.1016/j.pubrev.2004.02.004

Fishbein, M., \& Ajzen, I. (2010). Predicting and changing behavior: The reasoned action approach (pp. xix, 518). Psychology Press.

Flynn, T. (2004). Communication and Leadership In Times of Crisis. ResearchGate. https://www.researchgate.net/publication/329523370_Communication_and_Leadershi $\mathrm{p}$ In Times of Crisis

Hale, J. E., Dulek, R. E., \& Hale, D. P. (2005). Crisis Response Communication Challenges: Building Theory From Qualitative Data. The Journal of Business Communication (1973), 42(2), 112-134. https://doi.org/10.1177/0021943605274751

Hearit, K. M. (1999). Newsgroups, activist publics, and corporate apologia: The case of Intel and its Pentium chip. Public Relations Review, 25(3), 291-308. https://doi.org/10.1016/S0363-8111(99)00020-X

Kominfo. (2020a). Gugus Tugas Nasional Luncurkan Awal Sistem Informasi Bersatu Lawan COVID. Website Resmi Kementerian Komunikasi Dan Informatika RI. https://kominfo.go.id:443/content/detail/26113/gugus-tugas-nasional-luncurkan-awalsistem-informasi-bersatu-lawan-covid/0/berita

Kominfo. (2020b). Presiden Teken Keppres Gugus Tugas Percepatan Penanganan Covid-19. Website Resmi Kementerian Komunikasi Dan Informatika RI. http://content/detail/25046/presiden-teken-keppres-gugus-tugas-percepatanpenanganan-covid-19/0/berita

Martín, E. (2014). How to write a good article. Current Sociology, 62(7), 949-955. https://doi.org/10.1177/0011392114556034

Persada, S. (2020a). 3 Kritik JK Soal Cara Pemerintah Tangani Covid-19. Tempo. https://nasional.tempo.co/read/1345654/3-kritik-jk-soal-cara-pemerintah-tanganicovid-19

Persada, S. (2020b, April 11). Human Right Watch: Pemerintah Tak Transparan Soal Data Covid-19. Tempo. https://nasional.tempo.co/read/1330360/human-right-watchpemerintah-tak-transparan-soal-data-covid-19

Pomerantz, A. (1978). chapter 3 - Compliment Responses: Notes On The Co-Operation Of Multiple Constraints. In J. Schenkein (Ed.), Studies in the Organization of Conversational Interaction (pp. 79-112). Academic Press. https://doi.org/10.1016/B978-0-12-623550-0.50010-0

Pranita, E. (2020). Berbagai Respons Rakyat untuk Pemerintah Terkait Penanganan Covid19. KOMPAS.com.

https://www.kompas.com/sains/read/2020/04/02/100200323/berbagai-respons-rakyatuntuk-pemerintah-terkait-penanganan-covid-19

Prayogo, C. (2020, May 3). Aturan Mudik Banyak Revisi, Masyarakat Bingung. Warta Ekonomi. https://www.wartaekonomi.co.id/read283855/aturan-mudik-banyak-revisimasyarakat-bingung

Shihab, N. (2020a). Jokowi Diuji Pandemi - Jokowi: Mudik dan Pulang Kampung Itu Beda (Part 2) | Mata Najwa. https://www.youtube.com/watch?v=BC6F6Uxw1G0

Shihab, N. (2020b). Jokowi Diuji Pandemi: Didesak Mundur, Menkes Terawan Dipuji Jokowi (Part 1) | Mata Najwa. https://www.youtube.com/watch?v=JFHHzLixfXA

Shihab, N. (2020c). Jokowi Diuji Pandemi: Jurus Jokowi Atasi Dampak Pandemi (Part 4)। Mata Najwa. https://www.youtube.com/watch?v=jNh25GVy0kQ

Shihab, N. (2020d). Jokowi Diuji Pandemi: Mengapa Kini Jokowi Ingin Data Corona Dibuka (Part 3) | Mata Najwa. https://www.youtube.com/watch?v=yPtuSbC09MI 
Jurnal Ilmu Komunikasi UHO : Jurnal Penelitian Kajian Ilmu Komunikasi dan Informasi.

Volume 6, No. 1, Januari 2021, hlm 77-97

Sturges, D. L. (1994). Communicating through Crisis: A Strategy for Organizational Survival. Management Communication Quarterly, 7(3), 297-316.

Ulya, N. F. (2020). Pemerintah Anggarkan Rp 405 Triliun untuk Tangani Corona, Apakah Sudah Ideal? KOMPAS.com.

https://money.kompas.com/read/2020/04/26/140000426/pemerintah-anggarkan-rp405-triliun-untuk-tangani-corona-apakah-sudah-ideal-

Zhang, E., \& Benoit, W. L. (2009). Former Minister Zhang's discourse on SARS: Government's image restoration or destruction? Public Relations Review, 35(3), 240246. https://doi.org/10.1016/j.pubrev.2009.04.004

Zhang, J., \& Benoit, W. L. (2004). Message strategies of Saudi Arabia's image restoration campaign after 9/11. Public Relations Review, 30(2), 161-167. https://doi.org/10.1016/j.pubrev.2004.02.006 